\title{
Cultivation of Translation Competence - A Study on Translation Teaching in College English Teaching in Leshan Normal University, Sichuan, China
}

\author{
Ye Zhou \\ School of Foreign Language, Leshan Normal University, China \\ Li Zou \\ School of Foreign Language, Leshan Normal University, China
}

\begin{abstract}
The paper probes into the translation competence of non-English majors in college English study, based on a study carried out in Leshan Normal University in terms of translation teaching in college English teaching. Questionnaires on EFL teachers and students as well as data analysis are implemented with an aim to find out the current problems of translation teaching in college English and non-English majors' translation competence. Based on the problems, the author draws the conclusions and raises some suggestions, trying to help non-English majors to improve their translation competence and also to help EFL teachers to perfect their teaching approaches in translation teaching. The paper's findings are supposed to not only apply to Leshan Normal University but also apply to other colleges and universities in China.
\end{abstract}

Index Terms - translation competence, College English teaching, translation teaching; cultivation

\section{INTRODUCTION}

With the development of globalization, English is more and more commonly used in all sectors of society in China. And more and more students, especially college students, are making efforts to improve their English. For non-English majors in Chinese colleges and universities, translation competence is a good proof to show their comprehensive abilities of English. The command of translation competence decides one's ability to get information, to communicate with others as well as reading comprehension to the articles. In the process of translation, all skills such as listening skill, speaking skill, reading skill and writing skill are involved. Thus, it is of necessity to improve non-English majors' translation competence. In order to do this job, the current problems in translation teaching need to be found out in the first place. Based on a study carried out in Leshan Normal University, the paper is not only to find the current problems existing in translation teaching, but also to give advice to EFL teachers in teaching approaches.

\section{Previous Studies of Translation Teaching}

In his book Beyond the Ivory Tower: Rethinking Translation Pedagogy, Baer \& Koby (2003) made a detailed analysis and interpretation about such elements on translation teaching as translation theory, translation evaluation, cultural differences, translation progress, and further discussed some approaches to translator training, as well as some of the pedagogical opportunities and changes, etc. Colina (2003) probed into how to put the translation teaching theories into practice in his book Translation Teaching from Research to the Classroom: A Handbook for Teachers, with a hope to find an appropriate way for translation teachers to improve their translation teaching. In addition, Gonzalez Davies (2004), in his book Multiple Voices in the Translation Classroom: Activities, Task and Projects, provided us with great teaching ideas which is able to be used to various learning environments and under different language contexts, based on Humanistic, Communicative and Socio-constructivist theories. Clear goals are set up in the book for the students' activities in their translation learning process like making decisions and communicating with one anther, which begin from the most fundamental level of the word to the more complicated level of phrases, syntax and passages, and finally to the most difficult level of cultural clashes. The book is not only of great interest to all foreign language teachers and translation teachers who would like to combine translation into their classes, but also of big interest to those English majors who want to become teachers after graduation, and to those educators or administrators who are thinking about devising a new translation program.

Domestically, a lot of studies and researches on translation teaching have been done by language experts and teachers in China, especially after the increasing role of English in everyday life. With the further studies and researches of translation, scholars begin to be aware of the significance of translation to English competence. There is an important 
book that need to be mentioned, that is Translation Teaching and Research in China written by Mu Lei (1999), which analyzed in a systematical way the status quo of Chinese translation teaching in the aspect of discipline construction, curriculum designing, textbook construction, teachers training, teaching approaches, interpretation teaching, translation test and teaching research, etc. And the book has stirred up the interests of scholars and educators in translation teaching, encouraging more and more EFL teachers to make further research about the translation teaching reform. In his paper Foreign Language Education: Translation Teaching Reform Need Reinforcement in New Century published in Foreign language Research, Xu Jun (2000) stressed the necessity of reform in translation teaching in China. In addition, when it comes to translation tests, Chen Xiaowei (2002) analyzed the common mistakes and errors that are often made by the students in translation parts in English tests like TEM-8, in her paper Some Reflections on the Translations Produced by TEM-8 Candidates (published in Chinese Translators Journal). Besides, she pointed out the significance of translation and further put forward advice for the translation reform.

\section{RESEARCH DESIGN}

The author implemented the research from September 2016 to January 2017 in Leshan Normal University, Sichuan Province, China. And the research is done through the following four stages: stage one is questionnaire design and subjects selection; stage two is questionnaires survey and data recollection as well as some interviews with the EFL teachers; the third stage is data analysis by SPSS 13.0; and the final stage is reaching conclusion and composing research paper.

\section{Reasearch Subjects}

In the research, for students' part, two hundred and fifty second-year non-English majors from Leshan Normal University were selected at random as the research subjects, who came from different colleges including College of Chinese, College of Computer, College of Mathematics and Information, and College of Economics, etc. The reason why the author chose these colleges is that English level of the students from these colleges are comparatively good than other non-English majors from colleges of PE, college of Art or college of Music, etc.

And for teachers' part, 30 EFL teachers who teach non-English majors are chosen to conduct the research. Since the author is the colleague of all the subjects, it is very convenient to carry out questionnaire survey and the findings of data analysis can be further certified by causal talks and interviews.

\section{Research Questions}

The research questions about the English translation teaching and the student's translation competence are listed as follows:

For teachers:

1. What are the majors of teachers? Are they majored in translation?

2. What are their general view of English translation?

3. Is it necessary to put translation into English test? If it is necessary, what is the weight of translation in tests?

4. What are the translation teaching theories and approaches adopted by the teachers? Do they introduce them to the students?

5. What is the importance of translation teaching in college English?

6. What are decisive factors in translation teaching?

For students:

1. Can translation competence improve your English a lot?

2. What kind of translation theory do you know?

3. What are the problems and difficulties in translation learning?

4. What are important factors in translation?

5. What are suggestions to teachers in translation teaching?

6. Is translation indispensable in English tests?

\section{Questionnaire Design}

The questionnaires for both teachers and students have ten multiple-choice questions respectively. The questionnaires for the students include three parts: basic translation competence, attitudes towards translation and main problems in translation learning. The questionnaires for the teachers contain three parts: experience on translation teaching, translation theories and teaching approaches, decisive factors in translation.

\section{Procedures}

Firstly, the author gave questionnaires to 50 students and 5 teachers as a pretest to find the possible problems which may appear in the survey. Then the main study was implemented and all the questionnaires were handed out to all two hundred and fifty research subjects during their English class with the aid of their English teachers who told all the subjects that they should complete the questionnaires conscientiously, honestly on their own without signing their names on the questionnaires within fifteen minutes. Later, all the $30 \mathrm{EFL}$ teachers finish the questionnaires and some causal talks and interviews were done so as to improve the accuracy and validity.

\section{Data Collection and Data Analysis}

When all the questionnaires are finished, the author recollected them and input the data into computers for further study and analysis. Specifically, for students' part, two hundred and forty five valid questionnaires were recollected, and 
the other five were invalid for three subjects failed to complete all the questions and the other two wrote more choices than required; and for EFL teachers' part, all 30 valid questionnaires were recollected. With the help of the SPSS 13.0, the author analyzed the valid data. Besides, in the process of data analysis the author talked casually with some teachers who did the survey and carried out some short interviews with them as well, with an aim to understanding the results better and to certifying the validity of the results, and with an effort to find more problems in their translation teaching.

\section{MAJOR Findings OF THE RESEARCH RESUlTS}

\section{Findings in the Aspect of Teachers}

1. The research shows that most of the EFL teachers who did the questionnaires are not majored in translation. So in this sense, they are not very competent in teaching translation. Even the teachers need training in terms of translation strategies and skills. And this job is a long-term and tough one in that the teaching tasks are great burdens to the teachers who can hardly find time pursuing further training. Teachers' professional development is of great importance to the translation teaching and learning.

2. The research shows that most of the EFL teachers who did the questionnaires strongly hold the opinion that it is necessary put translation into English tests because the translation competence is a good proof for the students' comprehensive abilities in English. And further, most of the teachers advocate that the translation's weight in English tests should be raised in various kinds of form and even translation theories are tested in order to improve the students' theoretical knowledge.

3. The research shows that most of the EFL teachers who did the questionnaires attach great importance to translation theories. But in practical teaching, due to the limited English level and limited class time of non-English majors, they only introduce some methods, or techniques of translation to the students, which can hardly be called translation theories. Therefore, the teachers suggest that the school should offer translation as optional courses for those non-English majors who are interested in English translation.

4. The research shows that most of the EFL teachers who did the questionnaires firmly believe that translation is of substantial importance in their English teaching in that translation competence has a positive influence on other English abilities like listening, speaking, reading and writing. Besides translation exercises related to College English Test in which translation is tested, the teachers often provide other suitable materials for students to practice translation in their English classes.

5. The research shows that most of the EFL teachers who did the questionnaires maintain that cultural knowledge and translation skills are decisive factors in translation learning and teaching. Besides, comprehension of the source language is also important, which requires the students' vocabulary and reading competence. And further, the teachers suggest the students should practice a lot in translation so that they can master well transfer from source language to target language.

\section{Findings in the Aspect of Students}

1. The research shows that most of the non-English majors who did the questionnaires agree on that translation competence can reflect their English proficiency and translation can effectively improve their English. But on the other hand, most of the students are not confident about their translation competence so they spend less time in translation practice, which affects their English competence to a certain degree.

2. The research shows that most of the non-English majors who did the questionnaires fail to know translation theories, and probably are aware of some translation skills. They further point out that in their English class the teachers just ask them to do translation of new words or simple sentences, while for difficult sentences the teachers just give them translation answers directly. Thus, it is obvious that translation is just used as a tool to aid the teaching and the students do not put emphasis on translation theories.

3. The research shows that most of the non-English majors who did the questionnaires often have such problems and difficulties as lack of sufficient vocabulary and cultural knowledge in the process of translation. What's more, half of the students admit that they often feel difficult to understand the source language while another half of students acknowledge that they lack certain translation skills to translate long sentences and passages.

4. The research shows that most of the non-English majors who did the questionnaires regard vocabulary and grammar as the most decisive factors in translation practice. For non-English majors, it is understandable for them to ignore the importance of translation theories and cultural knowledge. In their mind, if they can know every word, every grammar, they can do the translation. Thus, the wrong belief need to be corrected in that translation is not merely a transfer from one language to another.

5. The research shows that most of the non-English majors who did the questionnaires would hope EFL teachers to introduce more materials related to their majors in translation practice rather than translation materials in tests like CET. From this aspect, it is clear that non-English majors study English out of their interest since the performance in English tests is not to decide whether they can graduate smoothly.

6. The research shows that most of the non-English majors who did the questionnaires think translation should not be a must, but a plus to English tests in that both translation and composition take a lot of time and they don't know how to prepare for it for it calls for a lot of practice. From this aspect, it is evident that the students still regard translation part as a difficult one and they feel reluctant to practice translation in their English study. 


\section{IMPLICATIONS OF THE RESEARCH}

Based on the above-mentioned findings, the author can get some implications as follows:

1. Cultivation of awareness and curiosity: There is no denying that the time for non-English majors to learn English, compared with the English majors, is limited. So the EFL teachers should try every means to make non-English majors aware of the importance of translation competence and arouse non-English majors' curiosity to spend more time in translation study. Only in this way can non-English majors take the initiative to find more translation materials for practice in their spare time, which will do them good in improving translation competence.

2. Curriculum adjustment of translation course: From the research, the author finds it necessary to adjust our existing curriculum of translation course so as to improve translation teaching. In Leshan Normal University, translation is not an individual course for non-English majors, but one part in the course of College English, which definitely fails to arouse non-English major' concern and curiosity. Therefore, it is high time that translation course was set up as optional course for non-English majors. Only in this way can those who are interested in translation are well-trained. To be a good translator, one must do a lot of translation practice and read a great deal of books. Only in specified translation course, the EFL teachers can assign more books related to translation to non-English majors.

3. Adjustment of translation exercises and translation tests: Based on the research findings, the author finds that the percentage of translation in the tests like CET-4 or CET-6 and that of translation exercises in the textbooks need to be raised up. Only in this way can the non-English majors really realize the importance of translation in their English study in that translation competence is an integrated competence of reading comprehension, language mastery, and cultural knowledge as well as composition skills.

4. Diversity of teaching materials: Based on the research findings, the author finds that it is beneficial for the EFL teachers to adopt proper materials in their translation teaching. With the development of globalization and the explosion of knowledge in this information society, the non-English majors have to be enriched in their knowledge. So they need to do a diverse range of translation materials. Further, to learn more and more about less and less is a must. Therefore, students with different majors should practice translation in certain fields. It is highly recommended that EFL teachers should cater to this need. In their translation teaching, they should choose special materials according to different students with different majors, not just to arouse the curiosity but also to meet the demand.

5. Variety of teaching activities: Based on the research findings, the author finds that it is necessary for the EFL teachers to adopt different teaching activities in their translation class. The EFL teachers should try to create a students-centered translation class instead of teacher-centered class. In translation class, the EFL teachers should not just ask the students to translate and then give the answers. Instead, they should adopt situational teaching method. For instance, they can take the students out of class to find signals and signs in the city for practice, which can not only arouse non-English majors' interest but also improve their translation competence.

6. Students' initiative in translation study. Based on the research findings, the author finds that the non-English majors' initiative in translation study matters a lot. In the first place, the students should establish confidence of translation, not just by teachers' help but by themselves. Then, to find suitable materials that are to their like is a good way for non-English majors. Finally, there are a lot of useful mobile-phone software and available tools on the internet that can help non-English majors a lot in improving their translation competence so long as they can use the ways in a right way.

\section{CONCLUSION}

It is widely acknowledged that some aspects in translation competence like psychological factors, physical conditions and cognitive ability are something people are born with, which plays a vital role in deciding whether he or she can develop into a great translator. But for ordinary translators, bilingual competence, professional knowledge, and translation skills and strategies, as well as practical translation matter more than those inborn factors. Therefore, most of people who are interested in translation have potential to improve their translation competence. And it is necessary to develop the translation competence by language training, classroom teaching and autonomous learning by the students at the same time. However, the translation teaching is not enjoying enough concern in college English teaching in most colleges and universities and this job still has a long way to go. On one hand, the administrative sections of education need to make changes in many aspects especially in the aspect of curriculum setting and tests adjustment, as well as training teachers for specialized translation strategies and skills. And on the other hand, both teachers and students should make joint efforts in translation teaching and learning under the guidance of the motto: "Interest is the best teacher."; "Practice makes perfect." Only in this way can we see the rosy aspect of improved translation teaching and cultivated translation competence.

\section{REFERENCES}

[1] Austermuhl, Frank. (2001). Electronic Tools.for Translators. Beijing: Foreign Language and Research Press.

[2] Baer Brian James \& Koby Geoffrey S. (2003). Beyond the Ivory Tower: Rethinking Translation Pedagogy. Amsterdam, Netherlands: Benjamins.

[3] Bassnett,S.and A. Lefevere. (1986). Constructing Culture: Essays on Literary Translation. Clevedon Philadelphia: Multilingual 
Matters Ltd.

[4] Bachman, L.F. (1990). Fundamental Considerations in Language Testing. London: Oxford University Press.

[5] Bowker Lynne. (2000). A corpus-based approach to evaluating student translations. Translator: Studies in Intercultural Communication. (2) 4-5.

[6] Chomsky, N. (1965). Aspects of the Theory of Syntax. Cambridge: MIT Press.

[7] Chen Xiaowei. (2002). Some Reflections on the Translations Produced by TEM-8 Candidates, Chinese Translators Journal, (1) 63-65.

[8] Colina Sonia. (2003). Translation Teaching From Research to the Classroom: A Handbook for Teachers. MA: McGraw-Hill.

[9] Cote Paul Raymond. (1990). From principles to pragmatics: Teaching translation in the classroom. French Review. (2) 11-13.

[10] Edwards. (1996). An introduction to the theory and practice of translation (2nd ed.). London \& New York: Routlesdge.

[11] Fox Olivia. (2000). The use of translation diaries in a process-oriented translation teaching methodology. Amsterdam, Netherlands: Benjamins.

[12] Gentzler E. (1993). Contemporary Translation Theories. London: Routledge.

[13] Gonzblez Davies Maria. (2004). Multiple Voices in the Translation Classroom: Activities, Tasks and Projects. Amsterdam, Netherlands: Benjamins.

[14] Hymes,D. (1967). On Communicative Competence. Harmondsworth: Penguin.

[15] Hughes, A. (1989). Testing for Language Teachers. London: Cambridge University Press.

[16] Luo Xuanmin. (2002). Chinese Translation Teaching: Problems and Prospect. Chinese Translators Journal. (4): 56-58

[17] Keith,H. (1998). Training of Translators, The Translator's handbook. London: Aslib and Contributors.

[18] Koby, Geoffrey S. and Baer, Brian James. (2003) Task-based instruction and the new technology. Amsterdam: John Benjamins Publishing Company, 211-227.

[19] Malmkjaer Kirsten. (1999). Stylistics in translation teaching. Perspectives: Studies in Translatology. (3): 37-39.

[20] Mu Lei. (1999). Translation Teaching and Research in China, Shanghai: Shanghai Foreign Language Education Press.

[21] McCarthy Brian. (2006).Tutoring translation skills: Reflections on a computer-managed teaching-learning-research triangle. CALL-EJ Online. (2): 40-42.

[22] Mossop, Brian. (2006). What should be taught at translation school. In: Anthony Pym, Perkrestenko Alexander and Starink Bram (et. al), Translation technology and its teaching. Tarragona: Servei de Publications: 15-37.

[23] Neubert, Albrecht. (2000). Competence in Translaiton. In: Christina Schaffner and Language, in Languages, and in Beverly Adab(eds.), Developing Translation Comptence. Amsterdam: John Benjamins.

[24] Newmark. P. (1988). Approach to Translation. London: Prentice Hall International Ltd.

[25] Nord Christiane. (2001). Translation as a Purposeful Activity: Functionalist Approaches Explained. Shanghai: Shanghai Foreign Language Education Press.

[26] Paper presented at the International Conference on Language Testing and Language Teaching. Shanghai: Shanghai Jiao Tong University.

[27] PACTS. (2000). Acquiring Translation Competence: Hypotheses and Methodological Problems in a Research Project. In: Allison Beeby, D. Ensinger, M. Presas (eds. Investigating Translation.) Amsterdam: John Benjamins: 99-106.

[28] PACTS. (2003). Building a Translation Competence Model. In: Alves F. (ed.), Triangulating Translation: Perspectives in Process Oriented Research. Amsterdam: John Benjamins: 43-66.

[29] Pym, Anthony. (2003). Refining Translating Competence in an Electronic Age. In Defense of a Minimalist Approach. Meta: Translators' Journal, (4):481-497.

[30] Spolsky, B. (1995). Measured Words. Oxford: Oxford University Press.

[31] Uwajeh M K C. (1994). Teaching Translation and Interpreting, Amsterdam: Benjamins.

[32] Waddington Christopher. (2004). Different methods of evaluating student translations: the question of validity. Metes: Translators' Journal. (2): 127-130.

[33] Wall, D. (2000). "The impact of high-stakes testing on teaching and learning: can this be predicted or controlled?". System. (1): 28-29.

[34] Wall, D. and J.C. Alderson. (1993). "Examining washback: The Sri Lankan impact study”. Language Testing. (2): 10-12.

[35] Wendland Ernst R. (2000). A Form-functional text-comparative method of translation, teaching, and checking. Notes on Translation. (1): 57-59.

[36] Wilss, Wolfram. (2001). The Science of Translation: Problems and Methods. Shanghai: Shanghai Foreign Language Education Press.

[37] Xu Jun. (2000). Foreign Language Education: Translation Teaching Reform Need Reinforcement in New Century, Foreign Language Research (2) 3-4.

Ye Zhou was born in Leshan City, Sichuan Province, China in 1983. She received her Master's Degree in Comparative Literature and World Literature from Sichuan International Studies University, China in 2012.

She is currently a lecturer in the School of Foreign Languages, Leshan Normal University, Sichuan, China. Her research interests include English teaching and American literature.

Li Zou was born in Leshan City, Sichuan Province, China in 1979. He received his Master's Degree in Education Technology from Southwest University, China in 2008.

$\mathrm{He}$ is currently an associate professor in the School of Foreign Languages, Leshan Normal University, Sichuan, China. His research interests include English teaching and American literature. 